\title{
Proteomics analysis of the photo-oxidation mutant 812HS rice (Oryza sativa L.) exposed to high light intensity
}

\author{
Chunfang $\mathrm{Lv}^{1}$, Jing $\mathrm{Ma}^{1 \dagger}$, Ze Yuan ${ }^{1}$, Yuwen Wang ${ }^{1}$, Guoxiang $\mathrm{Chen}^{1}$, Zhiping Gao ${ }^{1}$, Chuangen $\mathrm{Lv}^{2} *$ \\ ${ }^{1}$ School of Life Sciences, Nanjing Normal University, Nanjing 210023, China \\ ${ }^{2}$ Institute of Food and Crops, Jiangsu Academy of Agricultural Sciences, Nanjing 210014, China
}

*Corresponding author: E-mail: jiayoubwg@sina.cn

${ }^{\dagger}$ The author contributed equally to the paper.

\begin{abstract}
The $812 \mathrm{HS}$ rice line, a mutant of two-line sterile rice, exhibits leaf photo-oxidation during the tillering-jointing stage since its chloroplasts are susceptible to damage induced by strong sunlight. To determine the proteomic response to light intensity, the $812 \mathrm{HS}$ rice line was exposed to natural light and shade (about one fourth natural light), and two-dimensional electrophoresis in combination with matrix-assisted laser desorption/ionization time-of-flight/time-of-flight mass spectrometry was used to compare the proteomic expressions in the rice leaves. Although over 1000 reproducible proteins were detected, only $9.61 \%$ of them displayed differential expression with 1.5-fold abundance. A search of the National Center for Biotechnology Information database revealed 53 proteins, 34 down-regulated and 19 up-regulated under highlight. Among these identified proteins, six ones were related to disease and defense, implying the defense and protection mechanism was built under strong light stress. The increase in S-adenosylmethionine synthetase involved in the biosynthesis of the phytohormone ethylene might contribute to the phenotypic modulation from green to etiolation in photo-oxidation-sensitive leaves. These results suggest the existence of a complex regulatory mechanism of the proteomes in photo-oxidation-sensitive 812HS rice under light stress.
\end{abstract}

Keywords: 812HS rice (Oryza sativa L.); Light intensity; Photooxidation; Proteomic; Two-dimensional electrophoresis. Abbreviations: ACN_acetonitrile; ATP_adenosine triphosphate; CBB_coomassie brilliant blue; DTT_dithiothreitol; GAPDH_glyceraldehyde 3-phosphate dehydrogenase; IEF_isoelectric focusing; MALDI-TOF/TOF_matrix-assisted laser desorption/ionization time-of-flight/time-of-flight; OEC_oxygen-evolving complex protein; RCA_ribulose-1,5-bisphosphate carboxylase/oxygenase activase; RLS_rubisco large subunit; ROS_reactive oxygen species; TFA_trifluoroacetic acid; 2-DE-two dimensional electrophoresis.

\section{Introduction}

Rice (Oryza sativa L.) is not only a critically important food crop plant (Sasaki and Burr, 2000) but also an excellent model plant of cereal crops in scientific research. In the past few decades, studies of its physiology, ecology, genetic background, and molecular constitution have been performed (Komatsu et al., 2003). With the completion of the rice genome sequencing project, "rice proteomics" has entered the central stage of rice biology (Yu et al. 2002; Goff et al., 2002). Rice proteomics studies have focused on response to diverse abiotic (drought, salt) and biotic stresses, which provide fundamental insight into function of individual proteins along with their dynamic interaction network (Sun et al., 2014). Among the abiotic factors, light intensity and temperature can be considered to be the most serious factors limiting plant growth and yield (Foyer, 2002; Reddy et al., 2004). Kirchhoff found that sunlight intensity causes irreversible damage to photosynthetic apparatus in thylakoid membranes under high light conditions (Kirchhoff, 2014).

Light plays an essential role in plant photosynthesis, and the photosynthetic rate gradually increases as light intensity is enhanced. When the light energy absorbed by plants exceeds the capacity of light utilization in photosynthesis, photo-oxidation occurs (Reddy and Raghavendra, 2006). Photo-oxidation, one of the most deleterious phenotypic traits, can reduce photosynthetic productivity by $>10 \%$ (Ögren and Rosenqvist, 1992). Photo-oxidative stress in plants can cause the accumulation of reactive oxygen species (ROS), resulting in intracellular membrane lipid peroxidation and chlorophyll degradation (Ji et al., 2002), especially under photo-chilling, salinity, and drought stresses (Asada, 1999; Foyer and Noctor, 2000; Reddy et al., 2004). Numerous studies indicating multiplex protective mechanisms against the deleterious effects of photo-oxidative stress in photosynthetic apparatuses such as the xanthophyll cycle (Demmig-Adams and Adams, 1996), cellular antioxidant system (Matsubara et al., 2005), and photorespiration (Iacono and Sommer, 1996) were performed under high light irradiance. A comparative study of photo-oxidative damage differences was conducted in japonica and indica rice (Oryza sativa) under photo-oxidation and shading conditions. The study showed that the photo-oxidation-sensitive cultivar was easily harmed when exposed to photo-oxidation ( $\mathrm{Li}$ and Jiao, 2000).

The photo-oxidation mutant $812 \mathrm{HS}$ rice line was derived from a segregation population of the Indica photothermo-sensitive male sterile line $812 \mathrm{~S}$. The $812 \mathrm{HS}$ rice line showed the same agronomic traits as $812 \mathrm{~S}$ in the seedling stage; however, the leaves of the 812HS line turned yellow from the top by strong sunlight when the flag leave 
was spread, a phenomenon that was not noted in the $812 \mathrm{~S}$ line (Lai et al., 2012). Genetic analysis and gene mapping showed that photo-oxidation in the 812HS line was controlled by a new dominant leaf photo-oxidation 1 gene $(L P O 1(t))$, which was preliminarily mapped between RM307 and RM401 on a segment of chromosome 4 (Lai et al., 2012). The mutant provides very novel research material for further studies on the regulatory mechanism and associated gene function of photo-oxidation (Xia and Lv, 2012).

Most of the work to date on the physiological mechanisms of photo-oxidation in rice has been done under artificial photoinhibition conditions (Law et al., 2001). However, little is known about which proteins are responsive to photo-oxidation conditions in the $812 \mathrm{HS}$ line. In the present study, the proteome profile of $812 \mathrm{HS}$ flag leaves were analyzed using two-dimensional electrophoresis (2-DE) and matrix-assisted laser desorption/ionization time-of-flight/ time-of-flight (MALDI-TOF/TOF) mass spectrometer by shading, which could provide theoretical information for cultivating superior rice breeds in the future.

\section{Results and Discussion}

Comparison and functional classification of proteome map in $812 \mathrm{HS}$ rice

Proteomics analysis is an effective method for investigating the integral changes in the gene expression of plants under environmental stresses (Yan et al., 2006; Lee et al., 2009). To identify the differential expressions of proteins in rice treated with different light intensities, 2-DE was performed of the proteins extracted from the flag leaves. After CBB R-250 staining and software analysis, general proteome patterns under $\mathrm{pH}$ 4-7 were built for rice leaves (Fig. 1). A comparative analysis was conducted on these 2-DE gels using Image Master 2D Platinum software. A 1.5-fold quantitative change was set as the criterion, and 53 protein spots were differentially displayed in the $812 \mathrm{HS}$ rice line between the control and natural light treatment conditions (Table 1). Using the proteomic method, Yang et al. (2007) found some differential proteins of de-etiolated rice seedling responses to light stress and constructed the light-responsive network at the protein level.

The 53 identified proteins of diverse expression patterns could be divided into seven categories by function (Bevan et al. 1998) (Table 2). The most abundant category was energy-related proteins, while those involved in signal transduction, protein destination and storage, and secondary metabolism were seen at the same abundance in the identified proteins. The other functional categories included defense and unclear classification.

\section{Proteins involved in energy production}

The present study detected enhanced expression of glycine-rich proteins on signal transduction and identified some new light-responsive proteins including S-adenosylmethionine synthetase and glyceraldehyde 3-phosphate dehydrogenase (GAPDH). These changes provided new insight into the protein responses of plants to light exposure. In our study, a total of 53 differentially accumulated protein spots were analyzed and identified by MALDI-TOF/TOF mass spectrometry (Table 1). The most abundant identified proteins on our gels were involved in energy production. Among them, 17 were involved in energy production, including three related to light reactions of photosynthesis and 12 were associated with the carbon assimilation cycle as well as inorganic pyrophosphatase and nicotinamide adenine dinucleotide phosphate-dependent mannose 6-phosphate reductase. Adenosine triphosphate (ATP) synthetase F0 (spot no. 279) and oxygen-evolving complex protein1 (OEC) (spot nos. 112, 192) related to the light reactions of photosynthesis were down-regulated in the $812 \mathrm{HS}$ line compared with rice under shade condition. ATP synthetase F0 is an integral membrane enzyme that couples the free energy of proton transfer down an electrochemical gradient to the synthesis of ATP and the universal energy currency of all organisms (Yang et al., 2007). OEC is directly involved in water oxidation, located on the luminal side of photosystem II, and formed by several extrinsic proteins and a manganese cluster $\left(\mathrm{Mn}_{4} \mathrm{Ca}\right)$ (Zaharieva et al., 2011). Their down-regulation may have been attributed to a decrease in photosynthetic capacity in rice under high light stress.

\section{The proteins involved in the photosynthetic carbon assimilation cycle}

The proteins involved in the photosynthetic carbon assimilation cycle were all decreased except for ribulose-1,5-bisphosphate carboxylase/oxygenase activase (RCA), the key enzyme for the rapid formation of critical carbamate in the active site of the Rubisco activase protein. It is modulated either by a reaction with $\mathrm{CO}_{2}$ and $\mathrm{Mg}^{2+}$ to carbanylate, a lysine residue in the catalytic site, or by the binding of inhibitors within the catalytic site (Portis, 2003). Our result showed that RCA (spot no. 256) was strongly up-regulated in most expanded leaves of rice under stress. High light stress can reduce the photosynthesis either by impairing the Rubisco activation state, which is often attributed to RCA activity loss, or by reducing the abundance of Rubisco proteins. Thus, the up-regulated RCA could protect the photosynthesis machinery under high light stress. Despite similar protection from the RCA, different protective strategies were adopted by rice in different conditions. For instance, iorganic pyrophosphatase (spot no. 15) might contribute to improving protection against stress by increasing abundance. The spot no. 15 enzyme, on the other hand, plays an important role in sucrose synthesis (Kornberg, 1962), which synthesized polysaccharides from sucrose to enhance the plant's resistance to high light intensity (Aguilera et al., 1999).

Spots $(245,249,360,364$, and 280) were identified as the same protein, Rubisco large subunit (RLS). However, they were located at different positions on the gels, with similar $\mathrm{Mr}$ and $\mathrm{pI}$, indicating that they might be RLS isoforms. It can be assumed that the RLS is up-regulated under stress since its expression is enhanced. Spots no. 228, 244, 251, 286 and 336 were identified as ribulose-1,5-bisphosphate carboxylase large china precursor with similar $\mathrm{Mr}$ and $\mathrm{pI}$, which were down-regulated similar to ribulose-1,5-bisphosphate carboxylase (spot no. 14). A recent report showed that the sharp reductions in major leaf photosynthetic proteins, including the abundantly present ribulose-1,5-bisphosphate carboxylase/oxygenase, had occurred in the ozone condition. Ozone, a highly notorious environmental pollutant, has a damaging effect on rice seedlings at the proteome level (Agrawal et al., 2002). Thus, these results indicated that the decline in photosynthetic protein expression might be correlated with light and other stresses. Disease/defense proteins are also important for stress
response

In current experiment, hairpin binding protein 1 (spot no. 92), 
Table1. Protein identification through MALDI-TOF-MS.

\begin{tabular}{|c|c|c|c|c|c|c|}
\hline & $\begin{array}{l}\text { Accession } \\
\text { no. }\end{array}$ & Description/ Function & Score & $\begin{array}{l}\mathrm{SC} \\
(\%)\end{array}$ & $\begin{array}{l}\text { Theoretical } \\
\mathrm{Mr}\end{array}$ & $\begin{array}{c}\text { Theoretical } \\
\text { pI }\end{array}$ \\
\hline \multicolumn{7}{|c|}{ Decreased proteins } \\
\hline $1^{6}$ & gi|11466848 & Photosystem I subunit VII & 257 & 43 & 9406 & 6.51 \\
\hline $3^{7}$ & gi|115465862 & Os06g0101600 & 177 & 15 & 15624 & 5.61 \\
\hline $12^{7}$ & gi| 115434488 & Os01g0144100 & 227 & 11 & 20676 & 6.71 \\
\hline $19^{7}$ & gi| 115456241 & Os03g0820600 & 160 & 30 & 16050 & 5.72 \\
\hline $21^{5}$ & gi|2331133 & Glycine-rich protein & 39 & 14 & 16074 & 7.82 \\
\hline $40^{7}$ & gi|115477166 & Os08g0504500 & 290 & 23 & 25552 & 6.85 \\
\hline $43^{7}$ & gi|115484359 & Os11g0167800 & 260 & 18 & 15456 & 6.2 \\
\hline $47^{6}$ & gi|108862278 & Thylakoid lumenal $29.8 \mathrm{kDa}$ protein, putative, expressed & 325 & 30 & 19218 & 6.75 \\
\hline $64^{3}$ & gi|51090747 & Chaperonin 21 precursor, putative & 231 & 20 & 24835 & 7.68 \\
\hline $66^{2}$ & gi|11177845 & Glutathione S-transferase OsGSTF3, putative & 46 & 4 & 25117 & 5.81 \\
\hline $81^{7}$ & gi| 115474285 & Os07g0694700 & 435 & 22 & 27215 & 5.21 \\
\hline $88^{7}$ & gi|54290425 & Unknown protein & 232 & 11 & 34622 & 9.11 \\
\hline $97^{7}$ & gi|115460338 & Os04g0602100 & 315 & 12 & 38443 & 8.67 \\
\hline $120^{7}$ & gi|115478314 & Os09g0277800 & 71 & 33 & 39167 & 9.1 \\
\hline $124^{2}$ & gi|20286 & Peroxidase & 167 & 11 & 33311 & 5.77 \\
\hline $126^{7}$ & gi|115434036 & Os01g0106400 & 298 & 23 & 33481 & 5.69 \\
\hline $245^{1}$ & gi|11466795 & $\begin{array}{l}\text { Ribulose-1,5-bisphosphate carboxylase/oxygenase large } \\
\text { subunit }\end{array}$ & 288 & 12 & 53418 & 6.22 \\
\hline $256^{1}$ & gi|1778414 & Ribulose-1,5-bisphosphate carboxylase/oxygenase activase & 277 & 8 & 48055 & 5.85 \\
\hline $279^{1}$ & gi|194033257 & ATP synthase F0 subunit 1 & 165 & 47 & 55624 & 5.85 \\
\hline \multicolumn{7}{|c|}{ Increased proteins } \\
\hline $2^{7}$ & gi|115465862 & Os06g0101600 & 176 & 15 & 15624 & 5.61 \\
\hline $7^{7}$ & gi|38344542 & OSJNBa0027P08.10 & 172 & 23 & 16673 & 9.37 \\
\hline $8^{7}$ & gi|115441831 & Os01g0916600 & 272 & 23 & 15537 & 7.98 \\
\hline $14^{1}$ & gi|671740 & Ribulose-bisphosphate carboxylase & 221 & 31 & 15111 & 6.59 \\
\hline $39^{7}$ & gi| 115474635 & Os08g0129200 & 355 & 31 & 19024 & 6.28 \\
\hline $55^{7}$ & gi| 115478330 & Os09g0279500 & 186 & 10 & 26779 & 8.53 \\
\hline $57^{7}$ & gi| 125527970 & Hypothetical protein OsI_04011 & 310 & 19 & 21749 & 5.86 \\
\hline $92^{2}$ & gi|38679325 & Harpin binding protein 1 & 207 & 9 & 28457 & 8.92 \\
\hline $96^{7}$ & gi|115453797 & Os03g0565200 & 130 & 11 & 34138 & 8.36 \\
\hline $99^{7}$ & gi|115459134 & Os04g0490800 & 138 & 9 & 39811 & 6.75 \\
\hline $112^{1}$ & gi|739292 & Oxygen-evolving complex protein 1 & 72 & 8 & 26603 & 5.13 \\
\hline $123^{1}$ & gi|41053022 & $\begin{array}{l}\text { NADPH-dependent mannose 6-phosphate reductase, } \\
\text { putative }\end{array}$ & 162 & 9 & 35730 & 5.88 \\
\hline $133^{7}$ & gi|115448263 & Os02g0713400 & 73 & 12 & 34940 & 6.19 \\
\hline $172^{2}$ & gi|108705994 & $\begin{array}{l}\text { Glyceraldehyde-3-phosphate dehydrogenase B, chloroplast } \\
\text { precursor, putative, expressed }\end{array}$ & 261 & 11 & 34024 & 4.99 \\
\hline $187^{6}$ & gi|22748337 & Gln1-orysa glutamine synthetease root isozyme, putative & 115 & 11 & 38779 & 5.73 \\
\hline $192^{1}$ & gi|739292 & Oxygen-evolving complex protein 1 & 221 & 12 & 26603 & 5.13 \\
\hline $210^{7}$ & gi|115477843 & Os08g0562100 & 396 & 11 & 47492 & 6.96 \\
\hline $217^{4}$ & gi|3024122 & S-adenosylmethionine synthase 2 & 336 & 11 & 43330 & 5.68 \\
\hline $225^{7}$ & gi|116317759 & OSIGBa0127D24.2 & 186 & 46 & 52221 & 8.39 \\
\hline $228^{1}$ & gi|108862318 & $\begin{array}{l}\text { Ribulose bisphosphate carboxylase large chain precursor, } \\
\text { putative }\end{array}$ & 250 & 14 & 56547 & 9.04 \\
\hline $244^{1}$ & gi|108862318 & $\begin{array}{l}\text { Ribulose bisphosphate carboxylase large chain precursor, } \\
\text { putative }\end{array}$ & 110 & 10 & 56547 & 9.04 \\
\hline $246^{1}$ & gi|89280711 & ATP synthase F0 subunit 1 & 173 & 4 & 55532 & 5.85 \\
\hline $249^{1}$ & gi|11466795 & $\begin{array}{l}\text { Ribulose-1,5-bisphosphate carboxylase/oxygenase large } \\
\text { subunit }\end{array}$ & 356 & 9 & 53418 & 6.22 \\
\hline $251^{1}$ & gi|108862318 & $\begin{array}{l}\text { Ribulose bisphosphate carboxylase large chain precursor, } \\
\text { putative }\end{array}$ & 286 & 14 & 56547 & 9.04 \\
\hline $277^{7}$ & gi| 115436320 & Os01g0328700 & 266 & 14 & 53009 & 7.21 \\
\hline $278^{7}$ & gi|115436320 & Os01g0328700 & 149 & 52 & 53009 & 7.21 \\
\hline $280^{1}$ & gi|57283874 & $\begin{array}{l}\text { Ribulose-1,5-bisphosphate carboxylase/oxygenase large } \\
\text { subunit, partial }\end{array}$ & 114 & 51 & 53331 & 6.23 \\
\hline $286^{1}$ & gi|108862318 & Ribulose bisphosphate carboxylase large chain precursor, & 252 & 6 & 56547 & 9.04 \\
\hline
\end{tabular}




\begin{tabular}{|c|c|c|c|c|c|c|}
\hline & & putative & & & & \\
\hline $310^{7}$ & gi|38344034 & OJ991214_12.15 & 259 & 22 & 18271 & 4.67 \\
\hline $311^{2}$ & gi|149390991 & 2-cys peroxiredoxin bas 1 & 301 & 44 & 15404 & 5.13 \\
\hline $320^{7}$ & gi| 115448263 & Os02g0713400 & 187 & 10 & 34940 & 6.19 \\
\hline $336^{1}$ & gi|108862318 & $\begin{array}{l}\text { Ribulose bisphosphate carboxylase large chain precursor, } \\
\text { putative }\end{array}$ & 252 & 6 & 56547 & 9.07 \\
\hline $343^{2}$ & gi|75114857 & ATP-dependent zinc metalloprotease FTSH 2 & 297 & 6 & 72607 & 5.54 \\
\hline $360^{1}$ & gi|11466795 & $\begin{array}{l}\text { Ribulose-1,5-bisphosphate carboxylase/oxygenase large } \\
\text { subunit }\end{array}$ & 393 & 10 & 53418 & 6.22 \\
\hline $364^{1}$ & gi|11466795 & $\begin{array}{l}\text { Ribulose-1,5-bisphosphate carboxylase/oxygenase large } \\
\text { subunit }\end{array}$ & 191 & 6 & 53418 & 6.22 \\
\hline
\end{tabular}

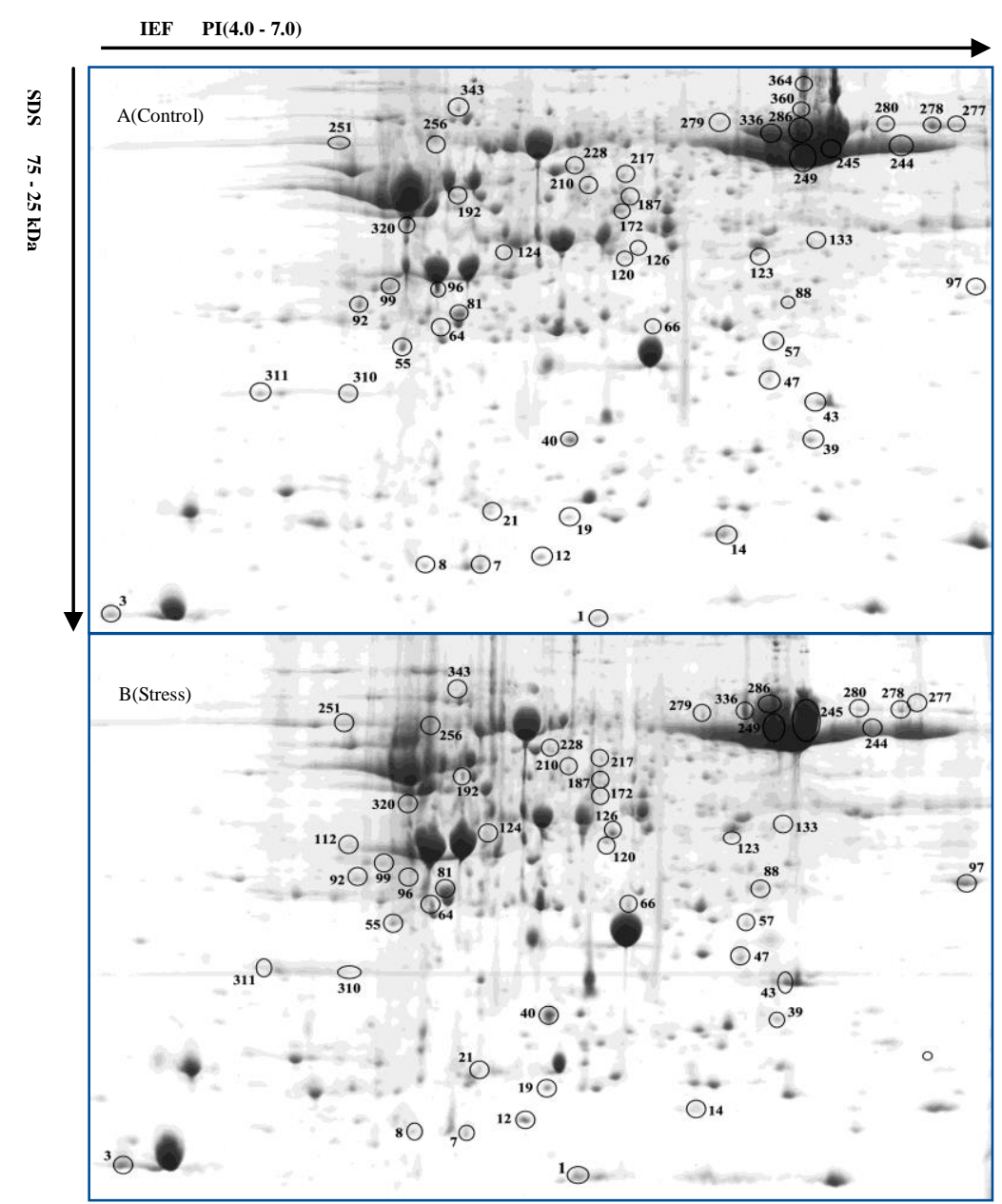

Fig 1. Protein analysis of $812 \mathrm{HS}$ rice leaves with control (A) and sunlight (B) in 812HS rice leaves. The differentially accumulated proteins between control and sunlight exclusion are indicated by circles and standard spot numbers on a representative gel. See Table 1 for a detailed list of proteins.

glyceraldehyde-3-phosphate dehydrogenase B (spot no. 172), ATP-dependent zinc metalloprotease FTSH2 (spot no. 343), and enzyme 2-cys peroxiredoxin bas1 (spot no. 311) were down-regulated, while glutathione S-transferase OsGSTF3 (66) and peroxidase (spot no. 124) and enzyme 2-cys peroxiredoxin bas1 (spot no. 311) were up-regulated. GAPDH is a central glycolytic protein with critical role in energy production and an abundant and key enzyme in glycolysis and gluconeogenesis in most plants (Sirover, 1999). Moreover, GAPDH is a protein with multiple functions involving the translational control of gene expression (Mezquita et al., 1998). For the last decade, there were many reports that GAPDH works as a stressor associated with oxidative stress in cells that undergo apoptosis (Saunders et al., 1997). It was also reported that GAPDH expression is naturally enhanced in Leishmania spp, which are naturally resistant to nitric oxide. The decreased expression of GAPDH may be a sign that the protective system response to light in the $812 \mathrm{HS}$ line was disintegrating. The hairpin protein group, which was first found and identified by Wei et al. (1992) in Erwinia amylovora, may result in multiple plant responses which have beneficial effects on crop improvement (Alfano and Collmer, 2004). The current results showed the possible defense mechanism 
Table 2. Classes and variation tendency of proteins identified on 2-D gels.

\begin{tabular}{|c|c|c|}
\hline Category & Spot number & $\mathrm{Up}(+) / \operatorname{down}(-)$ \\
\hline \multicolumn{3}{|l|}{ Energy production } \\
\hline ATP synthase F0 subunit 1 & 279 & - \\
\hline Oxygen-evolving complex protein 1 & 112,192 & - \\
\hline Ribulose-1,5-bisphosphate carboxylase/oxygenase activase & 256 & + \\
\hline Ribulose-1,5-bisphosphate carboxylase/oxygenase large subunit & $245,249,280,360,364$ & - \\
\hline Ribulose-bisphosphate carboxylase & 14 & - \\
\hline Ribulose bisphosphate carboxylase large chain precursor, putative & $228,244,251,286,336$ & - \\
\hline Inorganic pyrophosphatase & 70 & - \\
\hline NADPH-dependent mannose 6-phosphate reductase, putative & 123 & - \\
\hline \multicolumn{3}{|l|}{ Disease and defense } \\
\hline 2-cys peroxiredoxin bas 1 & 311 & - \\
\hline Peroxidase & 124 & + \\
\hline Glutathione S-transferase OsGSTF3, putative & 66 & + \\
\hline ATP-dependent zinc metalloprotease FTSH 2 & 343 & - \\
\hline $\begin{array}{l}\text { Glyceraldehyde-3-phosphate dehydrogenase B, chloroplast precursor, putative, } \\
\text { expressed }\end{array}$ & 172 & - \\
\hline Harpin binding protein 1 & 92 & - \\
\hline \multicolumn{3}{|l|}{ Protein destination and storage } \\
\hline Chaperonin 21 precursor putative & 64 & + \\
\hline \multicolumn{3}{|l|}{ Secondary metabolism } \\
\hline S-adenosylmethionine synthase 2 & 217 & - \\
\hline \multicolumn{3}{|l|}{ Signal transduction } \\
\hline Glycine-rich protein & 21 & + \\
\hline \multicolumn{3}{|l|}{ Unclear classification } \\
\hline Photosystem I subunit VII & 1 & + \\
\hline Thylakoid lumenal $29.8 \mathrm{kDa}$ protein, putative, expressed & 47 & + \\
\hline Gln1-orysa glutamine synthetease root isozyme, putative & 187 & - \\
\hline
\end{tabular}

a) The "+" represents the up-regulated protein spot on the 2-D gels. b) The "-" represents the down-regulated protein spot on the 2-D gels.

defense mechanism of rice plants in response to light by inducing hairpin proteins, thus enhancing photosynthesis and acclimatization. The significantly up-regulated glutathione S-transferase OsGSTF3 as well as down-regulated hairpin binding protein 1 was found in highly light-stressed 812HS line, which protects cells from injury induced by a wide range of stresses in plants (Marrs, 1996). Furthermore, the overexpression of the glutathione S-transferase gene improves the tolerance of Arabidopsis to salinity and oxidative stresses (Sharma, 2014). In addition, ROS generation is usually increased when the stresses are treated. ROS is mostly generated by the absorption of excess excitation energy leading to the over-reduction of the electron transport chains in plants subjected to photo-oxidative stress (Reddy and Raghavendra, 2006). Simultaneously, non-enzymatic and enzymatic systems might contribute to enhancing plant resistance. In our study, 2-cys peroxiredoxin bas1 (spot no. 311) and peroxidase (spot no. 124), which effectively repaired ROS-injured tissue, were up-regulated. Our proteomics analysis was consistent with that induced by peroxidases, and 2-cysteine peroxiredoxins were deemed crucial in controlling chain-type reactions following the initiation of lipid peroxidation in plant cell membranes (Baier and Dietz, 1999; Mullineaux and Karpinski, 2002). ATP-dependent zinc metalloprotease, which is mainly located in the thylakoid membrane, contributes to membrane protein regulation (Paulo et al., 2003). The filamentation temperature sensitive $\mathrm{H}$ protein precursor and other molecular chaperonin and enzymes correlated with proteometabolism were found in rice seeding responses to cold stress (Mann et al., 2000). In our study, the different changes in proteins might contribute to improving the stronger light resistance in the response of rice to environmental stresses and alleviating the damage induced by stresses (Nopvím et al., 2004).

\section{Proteins related to signal transduction}

On signal transduction, the abundance of glycine-rich protein (spot no. 21) in rice under light stress is higher than that of rice exposed to shade, which is attributed to extracellular signaling transduction, damage repair, RNA shearing, ripening, and gene expression (Ringli et al., 2001). We found that it plays important roles in stress resistance, and their accumulation could alleviate the damage induced in plants under stresses. In addition, S-adenosylmethionine synthetase, which is related to phytohormone synthesis, was increased under shade conditions. S-adenosylmethionine synthetase, which catalyzes the biosynthesis of S-adenosylmethionine from l-methionine and ATP, acts as a precursor molecule in the biosynthesis of the phytohormone ethylene (Yang and Hoffman, 1984). Research has shown that the accumulation of S-adenosylmethionine synthetase induced by salt stress may play a role in adaptation to salt stress (Espartero et al., 1994).

\section{Materials and Methods}

\section{Rice material}

The 812 HS rice line (Oryza sativa L. indica cultivar) was 
grown in pots under natural light (PFD 2500-3000 $\mu \mathrm{mol} \cdot \mathrm{m}^{-2} \cdot \mathrm{s}^{-1}$ ) and shade (PFD $600-800 \mu \mathrm{mol} \cdot \mathrm{m}^{-2} \cdot \mathrm{s}^{-1}$ ). The flag leaves were spread and collected (Xu et al., 2016). The samples were immediately frozen in liquid nitrogen and kept at $-80^{\circ} \mathrm{C}$ until the protein extraction step (Yang et al., 2006).

\section{Protein extraction}

Protein extraction was performed according to Wang et al. (2006) by phenol extraction methanol/ammonium acetate precipitation.

\section{Two-dimensional electrophoresis}

The 2-DE was performed according to Carpentier et al. (2005) with some alterations. The sample was diluted with isoelectric focusing (IEF) rehydration buffer ( $8 \mathrm{M}$ urea, $2 \%$ 3-[(3-cholamidopropyl) dimethylammonio]-1 -propanesulfonate, $50 \mathrm{mM}$ dithiothreitol (DTT), $0.2 \%$ Bio-Lyte 3/10 ampholyte, $0.001 \%$ bromophenol blue). Sample strips $24 \mathrm{~cm}$ long with pH 4-7 (Bio-Rad, Bio-Science) were rehydrated in $450 \mathrm{~mL}$ rehydration buffer containing approximately $1,000 \mathrm{mg}$ of proteins. The IEF was performed on an Ettan IPGphor II (GE Healthcare) at $2 \mathrm{~h}$ at $1000 \mathrm{~V}, 2 \mathrm{~h}$ at $500 \mathrm{~V}, 3 \mathrm{~h}$ at $1,000 \mathrm{~V}, 5 \mathrm{~h}$ at $8,000 \mathrm{~V}$ (gradient), and 80,000 $\mathrm{Vh}$ at $8,000 \mathrm{~V}$. After the first-dimensional run, gels were incubated for $15 \mathrm{~min}$ in $10 \mathrm{~mL}$ of equilibration buffer $(6 \mathrm{M}$ urea, 30\% glycerol, $2 \%$ SDS, $0.002 \%$ bromophenol blue, 75 $\mathrm{mM}$ Tris; $\mathrm{pH} 8.8$ ) containing $1 \% \mathrm{w} / \mathrm{v}$ DTT and subsequently for $15 \mathrm{~min}$ in $10 \mathrm{~mL}$ equilibration buffer including $2.5 \% \mathrm{w} / \mathrm{v}$ iodoacetamide. The 2-DE was performed on the Ettan DALTsix Electrophoresis System (GE Healthcare) with lab-cast $1.0 \mathrm{~mm}$ SDS polyacrylamide gels (12.5\%). After the electrophoresis, each gel was stained in $250 \mathrm{~mL}$ of Coomassie brilliant blue (CBB) solution containing $100 \mathrm{~mL}$ of methanol, $25 \mathrm{~mL}$ of acetic acid, and $0.25 \mathrm{~g}$ of CBB R-250.

\section{Protein visualization, image analysis and spot identification}

The stained gels were scanned at a 300 dpi resolution by an ImageScanner III (GE Healthcare) and the spot detection and gel comparison were performed using an Image Master ${ }^{\text {TM }}$ 2D Platinum version 7.0 software. Protein digestion and MALDI-TOF/TOF analyses were performed as described by Ning (2013) with light modification. First, the protein spots were individually excised from the gels. Each small gel piece with protein was destained with a solution containing 100 $\mathrm{mM} \mathrm{NH} \mathrm{NHCO}_{3}$ and $30 \% \mathrm{v} / \mathrm{v}$ acetonitrile (ACN) until each gel piece was colorless thoroughly. After being vacuum-dried, the gel pieces were rehydrated with $10 \mathrm{ng} / \mu \mathrm{L}$ trypsin (Promega, Madison, WI, USA) in $25 \mathrm{mM} \mathrm{NH}_{4} \mathrm{HCO}_{3}$ at $4^{\circ} \mathrm{C}$ for $1 \mathrm{~h}$ and then subjected to in-gel digestion in the same solution $37^{\circ} \mathrm{C}$ overnight. After digestion, the protein peptides were collected and the gels were washed with $0.1 \%$ trifluoroacetic acid (TFA) in $60 \%$ ACN to collect the remaining peptides. The peptides were re-dissolved in one volume of saturated $\alpha$-cyano-4-hydroxycinnamic acid in 50\% $\mathrm{v} / \mathrm{v}$ ACN containing $0.1 \%$ TFA. The resulting peptide mixture of each protein was analyzed by Ultraflex II MALDI-TOF/TOF mass spectrometer (Bruker Daltonik, Bremen, Germany). The peptide mass fingerprint data of each sample were acquired using Mascot software (http://www.matrixscience.com). Hits were considered significant according to the Mascot score $(\mathrm{p}<0.05)$.

\section{Conclusions}

In summary, our initial proteomic investigation reveals a complex cellular network of exposure to light in the 812HS rice line. The network consists of a broad range of metabolic processes, including energy production, disease/defense, protein destination and storage, secondary metabolism, signal transduction, and other unknown and unclassified proteins. The presence of these proteins with no clear functions indicated there is much to be learned about the molecular and proteomic events caused by sunlight stress. A future study on a comparative genome transcriptome analysis may be required, and whether the observed protein variations reflect changes in gene expression or some enzyme activities requires further confirmation.

\section{Acknowledgements}

This work was supported by the National Natural Science Foundaion of China Grant. No.31271621/C1302 and No.31671663, Project BK20140916 supported by NSF of Jiangsu Province of China, Program of Natural Science Research of Jiangsu Higher Education Institutions of China (Grant. No.14KJB180011), and a Project Funded by the Priority Academic Program Development of Jiangsu Higher Education Institutions. The authors have no conflict of interest to declare.

\section{References}

Agrawal GK, Rakwal R, Yonekura M, Kubo A, Saji H (2002) Proteome analysis of differentially displayed proteins as a tool for investigating ozone stress in rice (oryza sativa l.) seedlings. Proteomics. 2:947-959.

Aguilera J, Jiménez C, Figueroa FL, Lebert M, Häder DP (1999) Effect of ultraviolet radiation on thallus absorption and photosynthetic pigments in the red alga porphyra umbilicalis. J Photochem Photobiol B Biol. 48:75-82.

Alfano JR, Collmer A (2004) Type iii secretion system effector proteins: double agents in bacterial disease and plant defense. Annu Rev Phytopathol. 42:385-414.

Asada K (1999) The water-water cycle in chloroplasts: scavenging of active oxygen and dissipation of excess photons. Annu Rev Plant Physiol Plant Mol Biol. 50:601-640.

Baier M, Dietz KJ (1999) Protective function of chloroplast 2-cysteine peroxiredoxin in photosynthesis: evidence from transgenic arabidopsis. Plant Physiol. 119:1407-1414.

Bevan M, Bancroft I, Bent E et al. (1998) Analysis of $1.9 \mathrm{mb}$ of contiguous sequence from chromosome 4 of arabidopsis thaliana. Nature. 391:485-488.

Carpentier SV, Witters E, Laukens K, Deckers P, Swennen R, Panis B (2005) Preparation of protein extracts from recalcitrant plant tissues: an evaluation of different methods for two-dimensional gel electrophoresis analysis. Proteomics. 5:2497-2507.

Demmig-Adams B, Adams-Lii WW (1996) Xanthophyll cycle and light stress in nature: uniform response to excess direct sunlight among higher plant species. Planta. 198:460-470.

Espartero J, Pintor-Toro JA, Pardo JM (1994) Differential accumulation of s-adenosylmethionine synthetase transcripts in response to salt stress. Plant Mol Biol. 25:217-227.

Foyer CH (2002) The contribution of photosynthetic oxygen metabolism to oxidative stress in plants. In: Inze D, Van Montagu M, Eds oxidative stress in plants, New York, Taylor and Francis, pp.33-66.

Foyer CH, Noctor G (2000) Oxygen processing in photosynthesis: regulation and signaling. New Phytol. 146:359-388. 
Goff SA, Ricke D, Lan TH et al. (2002) A draft sequence of the rice genome (oryza sativa $l$. $\quad$ ssp. japonica). Science. 296:92-100.

Iacono F, Sommer KJ (1996) Photoinhibition of photosynthesis and photorespiration in vitis vinifera under field conditions-effects of light climate and leaf position. Aust J Grape Wine R. 2:1-11.

Ji BH, Zhu SQ, Jiao DM (2002) Photochemical efficiency of ps ii and membrane lipid peroxidation in leaves of indica and japonica rice (oryza sativa) under chilling temperature and strong light stress conditions. Acta Bot Sin. 44:139-146.

Kirchhoff H (2014) Structural changes of the thylakoid membrane network induced by high light stress in plant chloroplasts. Philos Trans R Soc Lond B Biol Sci. 369:1925-1953

Komatsu S (2003) Rice proteomics: a step toward functional analysis of the rice genome. Plant Mol Biol. 2:179-190.

Kornberg A (1962) On the metabolic significance of phosphorolytic and pyrophosphorolytic reactions. In Kasha H, Pullman B, ed, Horizons in biochemistry. Academic, New York. pp.251-264.

Lai D, Xia SJ, Lv CG, Wei XD, Liu SK, Zhang B, Liao HM, Yan WF, Zong SY, Zhang QJ (2012) Mapping a leaf photo-oxidation gene lpol(t) in rice. Jiangsu Agric Sci. 121:1212-1217.

Law RD, Crafts-Brandner SJ, Salvucci ME (2001) Heat stress induces the synthesis of a new form of ribulose-1,5-bisphosphate carboxylase/oxygenase activase in cotton leaves. Planta. 214:117-125.

Lee DG, Ahsan N, Lee SH, Lee JJ, Bahk JD, Kang KY, Lee BH (2009) Chilling stress-induced proteomic changes in rice roots. J Plant Physiol. 166:1-11

Li X, Jiao DM (2000) Physiological basis of photosynthetic tolerance to photooxidation and shading in rice. Acta Bot Sin. 42:1271-1277.

Mann NH, Novaca N, Mullineaux CW, Newmana J, Bailey S, Robinsona C (2000) Involvement of an ftsh homologue in the assembly of functional photosystem I in the cyanobacterium synechocystis sp. pcc 6803. Febs Lett. 479:72-77.

Marrs KA (1996) The functions and regulation of glutathione s-transferases in plants. Annu Rev Plant Physiol Plant Mol Biol. 47:127-158.

Matsubara S, Naumann M, Martin R, Nichol C, Rascher U, Morosinotto T, Bassi R, Osmond B (2005) Slowly reversible de-epoxidation of lutein-epoxide in deep shade leaves of a tropical tree legume may 'lock-in' lutein-based photoprotection during acclimation to strong light. J Exp Bot. $56: 461-468$

Mezquita J, Pau M, Mezquita C (1998) Several novel transcripts of glyceraldehyde-3-phosphate ehydrogenase expressed in adult chicken testis. J Cell Biochem. 71:127-139.

Mullineaux P, Karpinski S (2002) Signal transduction in response to excess light: getting out of chloroplast. Curr Opin Plant Biol. 5:43-48.

Nepovím A, Podlipná R, Soudek P, Schröder P, Vaněk T (2004) Effects of heavy metals and nitroaromatic compounds on horseradish glutathione s-transferase and peroxidase. Chemosphere. 57: 1007-1015.

Ning N, Cao Y, Wei D, Wu B, Li S (2013) Proteomic analysis of grape berry skin responding to sunlight exclusion. J Plant Physiol. 170:748-757.

Ögren E, Rosenqvist E (1992) On the significance of photoinhibition of photosynthesis in the field and its generality among species. Photosynth Res. 33: 63-71.

Paulo S, Elinor T, Shaun B, Olaf K, Mullineaux CW, Colin R (2003) Ftsh is involved in the early stages of repair of photosystem ii in synechocystis sp. pcc 6803. Plant Cell.15:2152-2164
Portis AR (2003) Rubisco activase-rubisco's catalytic chaperone. Photosynth Res. 75:11-27.

Reddy AR, Chaitanya KV, Vivekanandan V (2004) Drought-induced responses of photosynthesis and antioxidant metabolism in higher plants. J Plant Physiol. 161:1189-1202.

Reddy AR, Raghavendra AS (2006) Photooxidative stress. In Madhava Rao KV, Raghavendra AS, Reddy AR, Eds, Physiology and Molecular Biology of Stress Tolerance in Plants. Springer, The Netherlands, pp. 157-186.

Ringli C, Keller B, Ryser U (2001) Glycine-rich proteins as structural components of plant cell walls. Cell Mol Life Sci. 58:1430-1441.

Sasaki T, Burr B (2000) International rice genome sequencing project: the effort to completely sequence the rice genome. Curr Opin Plant Biol. 3:138-141.

Saunders M, Dische S, Barrett A, Harvey A, Griffiths G, Parmar M (1997) Continuous hyperfractionated accelerated radiotherapy (chart) versus conventional radiotherapy in non-small-cell lung cancer: a randomised multicentre trial. Lancet. 350:161-165.

Sharma R, Sahoo A, Devendran R, Jain M (2014) Over-expression of a rice tau class glutathione s-transferase gene improves tolerance to salinity and oxidative stresses in arabidopsis. PLoS One. 9:e92900.

Sirover MA (1999) New insights into an old protein: the functional diversity of mammalian glyceraldehyde-3-phosphate dehydrogenase. BBA-Protein Struct M. 1432:159-184.

Sun TK, Sang GK, Agrawal GK, Kikuchi S, Rakwal R (2014) Rice proteomics: a model system for crop improvement and food security. Proteomics. 14:593-610.

Wang W, Vignani R, Scali M, Cresti M (2006) A universal and rapid protocol for protein extraction from recalcitrant plant tissues for proteomic analysis. Electrophoresis. 27:2782-2786.

Wei ZM, Laby RJ, Zumoff CH, Bauer DW, He SY, Collmer A, Beer SV (1992) Harpin, elicitor of the hypersensitive response produced by the plant pathogen erwinia amylovora. Science. 257:85-88.

Xia SJ, Lv CG (2012) Research progress on leaf photooxidation in rice. Hybrid Rice. 27:1-8.

Xu JG, Lv CG, Liu L, Lv CF, Ma J, Xia SJ, Chen GX, Gao ZP (2016) Characteristics of photosynthesis and antioxidation in rice photo-oxidation mutant 812HS. Acta Agron Sin. 42: 574-582.

Yan SP, Zhang QY, Tang ZC, Su WA, Sun WN (2006) Comparative proteomic analysis provides new insights into chilling stress responses in rice. Mol Cell Proteomics. 5:484-496.

Yang PF, Chen H, LiangY, Shen SH (2007) Proteomic analysis of de-etiolated rice seedlings upon exposure to light. Proteomics. 7:2459-2468.

Yang PF, Liang Y, Shen SH, Kuang TY (2006) Proteome analysis of rice uppermost internodes at the milky stage. Proteomics. 6:3330-3338

Yang SF, Hoffman NE (1984) Ethylene biosynthesis and its regulation in higher plants. Annu Rev Plant Physiol. 35:155-189.

$\mathrm{Yu}$ J, Hu S, Wang J, Wong GK et al. (2002 ) A draft sequence of the rice genome (oryza sativa l. ssp. indica). Science. 296:79-92.

Zaharieva I, Wichmann JM, Holger D (2011) Thermodynamic limitations of photosynthetic water oxidation at high proton concentrations. J Biol Chem. 286:18222-18228. 